\title{
The Development and Application of an Educational Social Accounting Matrix
}

\author{
Xin-ji-le-tu YANG ${ }^{1, a}$, Zhen-yi ZHANG ${ }^{1, b}$ and Wei-hong HAN ${ }^{1, c}$ \\ ${ }^{1}$ School of Management, Inner Mongolia University of Technology, Hohhot, China, 010051 \\ àyangbill5872@yahoo.com, b405373292@qq.com, '975499382@qq.com
}

Keywords: Educational social accounting matrix, Multiplier analysis, Structural path analysis.

Abstract. Although social accounting matrix (SAM) method has been widely applied to the national economic accounting and economic development, it still ignores important information such as interactions between economy and education. In order to explain the relationship between economic activities and educational activities, this paper extends the SAM educationally based on Inner Mongolia 2007 data. The multiplier and structural path analyses are applied to the SAM for evaluating educational impacts of education-related economic and fiscal policies. The results show that the educationally extended SAM can be a useful tool in education policy analysis.

\section{Introduction}

The social accounting matrix (SAM) method has been widely applied to national accounting and economic development since it emerged in the early 1960s. Although the SAM, by building the relationships among production activities, factors of production and institutions, significantly extended the mufti-sectarian frame of the input-output table, it still ignores important information, in which there is an interaction between economy and education[1].This educational module integrated and extended the traditional SAM in order to achieve two objectives. Firstly, the matrix can provide an integrated, consistent data set to describe the relationships between economic activities and educational activities. Secondly, the extended SAM itself can be used as a modeling tool for policy analysis, especially for education-related policy analysis.

The first part reviews the development of the SAM; the second part will introduce the construction of an educationally extended SAM (ESAM). There are three innovations in this framework: educational activities are distinguished from production activities; primary education, secondary education and higher education are regarded as inputs in the production process particularly; labor has also been classified as illiterate, middle-level labor and high-level labor. In order to quantitatively describe the ESAM, the third part constructs the ESAM using 2007 Inner Mongolia Input and Output table and other educational data. According to this ESAM, the fourth part shows how to conduct the multiplier analysis and structural path analysis to assess the impact of economic policies on educational activities.

\section{Brief Review of the SAM}

As a comprehensive socioeconomic accounting system, SAM can describe the socioeconomic situation, check statistics and provide policy analysis tools.

The SAM is a matrix composed of a series of different accounts. Compared with the input-output technique, the SAM can describe the relationship between the various sectors of production activities and further integrate production activities, factors of production, income, consumption and capital accumulation into the accounting framework. Each row means the receipts of the corresponding agent, and each column implies the expenditures. As with any double-entry bookkeeping system, the corresponding row and column sums for any agent must be equal. 
Table1. A representative SAM framework

\begin{tabular}{|c|c|c|c|c|c|c|c|c|c|}
\hline & & Activities & Factors & Institutions & Government & Capital & $\begin{array}{l}\text { Rest of } \\
\text { province } \\
\text { (R.O.P) }\end{array}$ & $\begin{array}{l}\text { Rest of } \\
\text { world } \\
\text { (R.O.W) }\end{array}$ & Total \\
\hline & & 1 & 2 & 3 & 4 & 5 & 6 & 7 & 8 \\
\hline $\begin{array}{l}\text { Production } \\
\text { activities }\end{array}$ & 1 & $\begin{array}{l}\text { Intermediate } \\
\text { input (use) }\end{array}$ & & $\begin{array}{l}\text { Institutional } \\
\text { consumption }\end{array}$ & $\begin{array}{l}\text { Government } \\
\text { consumption }\end{array}$ & $\begin{array}{l}\text { Investme } \\
\text { nt }\end{array}$ & Call-out & Exports & Total sales \\
\hline Factors & 2 & $\begin{array}{l}\text { Factor } \\
\text { payment }\end{array}$ & & & & & & & $\begin{array}{l}\text { Value- } \\
\text { added }\end{array}$ \\
\hline Institutions & 3 & & $\begin{array}{l}\text { Allocation } \\
\text { matrix }\end{array}$ & & Transfer & & & & $\begin{array}{l}\text { Total } \\
\text { institutional } \\
\text { income }\end{array}$ \\
\hline Government & 4 & $\begin{array}{l}\text { Production } \\
\operatorname{tax}\end{array}$ & & Income tax & & & & & $\begin{array}{l}\text { Government } \\
\text { income }\end{array}$ \\
\hline Capital & 5 & & Depreciation & $\begin{array}{l}\text { Institutional } \\
\text { saving }\end{array}$ & $\begin{array}{l}\text { Government } \\
\text { saving }\end{array}$ & & $\begin{array}{l}\text { Saving } \\
\text { by R.O.P }\end{array}$ & $\begin{array}{l}\text { Saving } \\
\text { by R.O.W }\end{array}$ & Total saving \\
\hline $\begin{array}{l}\text { Rest of province } \\
\text { (R.O.P) }\end{array}$ & 6 & Call-in & & & & & & & $\begin{array}{l}\text { R.O.P } \\
\text { income }\end{array}$ \\
\hline $\begin{array}{l}\text { Rest of world } \\
\text { (R.O.W) }\end{array}$ & 7 & Imports & & & & & & & $\begin{array}{l}\text { R.O.W } \\
\text { income }\end{array}$ \\
\hline Total & 8 & Total cost & Value-added & $\begin{array}{l}\text { Total } \\
\text { institutional } \\
\text { expenditure }\end{array}$ & $\begin{array}{l}\text { Total } \\
\text { government } \\
\text { expenditure }\end{array}$ & $\begin{array}{l}\text { Total } \\
\text { invest }\end{array}$ & $\begin{array}{l}\text { R.O.P } \\
\text { expedite }\end{array}$ & $\begin{array}{l}\text { R.O.W } \\
\text { expedite }\end{array}$ & \\
\hline
\end{tabular}

Table1 shows a representative SAM framework. SAM includes part of the standard input and output table, i.e., the intermediate inputs in entry $(1,1)$, and some information about factors of production, institutions and so on. $(2,1)$ illustrates factors of production obtain income from producing sectors, and entry $(3,2)$ further allocates factor payments to households. And tax, savings and investment are also included in the SAM.

When a SAM is integrated using data from various sources, inconsistencies in data often arise. The inconsistency problem is sometimes because different definitions among the different accounts, but the main reason is the presence of measurement errors. It needs to force the processing of the raw data consistency. Many scholars have conducted research on data consistency. Among them, Dervis, DeMelo, and Robinson (1982) provided an approach for data adjustment in detail [2]. Qiwen Wang (2008) introduced a quadratic programming method to balance a SAM [3].

\section{Construction of an Educationally Extended SAM}

Economic activity has a profound impact on education. Few people have realized the importance of education-related data in national accounting systems. The newly revised Chinese System of National Accounts (CSNA) has also ignored the role of education. To overcome this shortcoming, Ji began revised the SNA in 1999 [4]. The revised version contains special public expenditure on education accounts for the education. Jinqin Zhu proposed an extended SAM and added education spending and human capital modules into the national accounting matrix. This SAM integrated economic accounts with education accounts for impacts of public educational expenditure. Economic flows in monetary terms and education effects in physical terms are combined into the single information framework[5].In order to describe the interactions between education and economic activities in an accounting system, this part develops an educationally extended SAM (ESAM), which can provide a modeling tool for the analysis of education policy. The ESAM is characterized by its separate accounts for education-related information, such as concerned with education sectors, primary education, secondary education and higher education.

The activity account is further divided into productive activities and educational activities in the matrix. Following Frontiers approach in his I/O tables (1970) [6], while primary education, secondary education and higher education are used by production sectors as special intermediate inputs. ESAM regards the education as a production factor. The sectarian payment for the inputs of educational services, such as the income of primary education, secondary education and higher education is given. In fact, estimating and internalizing the educational value of these services is difficult. The educational 
investment and R\&D investment come from the local government. Governmental efforts in education also include local government purchase of primary education. Central government purchase of higher education. Educational benefit by production activities to the enterprises for the human resources provided by household, general enterprise transfers to households. Household purchase of secondary education, if there are some.

The ESAM could be traced by educational themes for measuring the educational impacts of educational investment and R\&D investment. Feedback from the education on the economy, e.g., the positive effects of education on productivity and on the effectiveness of factor and intermediate inputs, could be separately accounted for in an ESAM. Due to lacking this complex research at the macro level, the impacts of education on production are rather implicitly represented by production output in the current matrix.

\section{Inner Mongolia Education Social Accounting Matrix (ESAM)}

A numerical ESAM which can be integrated by adopting Inner Mongolia data contribute to demonstrate how to develop an ESAM. The ESAM has twelve production sectors (agriculture, metallurgy industry, chemical industry, manufacturing, light industry, construction, transportation, services and coal, oil, gas and electricity), three types of education (primary education, secondary education and higher education), and three corresponding labor factors (illiteracy, medium level labor and higher level labor).

Based on the existing I/O table and SAM of Inner Mongolia, a twelve-sector SAM was constructed first. The data of intermediate inputs, value added, and consumption were aggregated from Inner Mongolia' 42-sector I/O table. The data on trades, taxes, subsidies, and debt came from 2008 China Statistical Yearbook[7]. Beginning with the twelve-sector SAM, the ESAM was built by separating educational activities from economic activities.

The educational sectors were separated from the existing twelve production sectors in the activity account. After the intermediate inputs of the education sectors were separated from those of the production sectors, the spending of production sectors on the primary education, secondary education and higher education of three educational sectors was estimated in the activity matrix. The institutions were divided into two parts: the general business institution and educational institution.

According to 2007 National Education Funding Statistical Bulletin, China gave 1.214807 trillion yuan for National Education funding, which has an increase of $23.77 \%$ over 981.531 billion yuan of last year. Among them, the state education budget (including financial allocations for education at all levels, the collection of taxes, corporate funding of schools and run industry tax breaks for education and other items) was 828.021 billion yuan, increased by $30.43 \%$ than 6348.36 billion yuan of last year. The educational investment was transferred to the production sectors as investment consumption demands in the activity rows of the educational investment column.

\section{Multiplier and Structural Path Analysis within the ESAM}

Firstly, separate the ESAM into endogenous and exogenous accounts. The endogenous accounts contain the production sectors, education sectors, production factors, household and enterprises. The rest accounts of the table are combined into an exogenous account. Secondly, calculate the matrix of average expenditure propensities of endogenous variables ( $\mathrm{An}$ ) by dividing each endogenous element by corresponding column sum in the ESAM. Compared with the technical coefficient matrix AI in an input-output model, we further integrate the production factors, household, enterprises into the endogenous matrix. Thirdly, calculate the ESAM multiplier matrix Ma via the formula:

$$
\mathrm{Ma}=(\mathrm{I}-\mathrm{An})-1
$$

Table 2 shows the part of the ESAM multiplier matrix. The value of an element in the multiplier matrix Ma represents that a unit of change in the exogenous account of the agent in the column can 
cause the amount of the changes in the agent in the row. The multiplier in cell $(4,15)$ means that, per unit increase in higher education output (agent \#15), raises manufacturing output (agent 4\#) by 0.1511 .

Table2. The part of ESAM multiplier matrix

\begin{tabular}{|c|c|c|c|c|c|c|c|c|c|c|c|c|}
\hline & & M & $\mathrm{L}$ & B & $\mathrm{T}$ & $\mathrm{S}$ & $\mathrm{H}$ & HL & $\mathrm{NC}$ & $\mathrm{U}$ & $\mathrm{G}$ & $\mathrm{E}$ \\
\hline & & 4 & 5 & 6 & 7 & 8 & 15 & 18 & 19 & 22 & 23 & 24 \\
\hline Manufacturing & 4 & 1.6661 & 0.2440 & 0.6289 & 0.3076 & 0.2505 & 0.1511 & 0.3051 & 0.2242 & 0.3814 & 0.2252 & 0.2252 \\
\hline Light & 5 & 0.2424 & 1.5264 & 0.2256 & 0.3067 & 0.2497 & 0.1659 & 0.4755 & 0.3494 & 0.5943 & 0.3509 & 0.3509 \\
\hline Building & 6 & 0.0164 & 0.0178 & 1.0139 & 0.0232 & 0.0215 & 0.0130 & 0.0274 & 0.0202 & 0.0343 & 0.0203 & 0.0203 \\
\hline Transport & 7 & 0.3574 & 0.2391 & 0.3134 & 1.3299 & 0.1706 & 0.1255 & 0.2111 & 0.1552 & 0.2639 & 0.1558 & 0.1558 \\
\hline Service & 8 & 0.7328 & 0.7293 & 0.5839 & 0.7162 & 1.5966 & 0.4503 & 0.8497 & 0.6245 & 1.0621 & 0.6272 & 0.6272 \\
\hline $\begin{array}{l}\text { Higher } \\
\text { education }\end{array}$ & $\begin{array}{l}1 \\
5\end{array}$ & 0.0137 & 0.0165 & 0.0123 & 0.0155 & 0.0125 & 1.0080 & 0.0357 & 0.0262 & 0.0446 & 0.0263 & 0.0263 \\
\hline $\begin{array}{l}\text { Higher } \\
\text { Level }\end{array}$ & $\begin{array}{l}1 \\
8\end{array}$ & 0.0743 & 0.0666 & 0.0789 & 0.0698 & 0.0709 & 0.0581 & 1.0541 & 0.0397 & 0.0676 & 0.0399 & 0.0399 \\
\hline Net & $\begin{array}{l}1 \\
9\end{array}$ & 0.5850 & 0.7376 & 0.5156 & 0.6825 & 0.4977 & 0.2435 & 0.4722 & 1.3470 & 0.5903 & 0.3485 & 0.3485 \\
\hline Urban household & $\begin{array}{l}2 \\
2\end{array}$ & 0.4034 & 0.4869 & 0.3662 & 0.4571 & 0.3494 & 0.1897 & 1.1209 & 0.8238 & 1.4011 & 0.8274 & 0.8274 \\
\hline General business & $\begin{array}{l}2 \\
3\end{array}$ & 0.4590 & 0.5786 & 0.4045 & 0.5354 & 0.3905 & 0.1911 & 0.3704 & 1.0567 & 0.4631 & 1.2734 & 0.2734 \\
\hline $\begin{array}{l}\text { Educational } \\
\text { institution }\end{array}$ & $\begin{array}{l}2 \\
4\end{array}$ & 0.0940 & 0.1185 & 0.0829 & 0.1097 & 0.0800 & 0.0391 & 0.0759 & 0.2165 & 0.0949 & 0.0560 & 1.0560 \\
\hline
\end{tabular}

Note:The meaning of each column of the letter consistent with the corresponding line.

ESAM multiplier matrix provides simulation result about the impacts of education policy shock on education-related activities. Row15 in the table gives the multiplier for the higher education sector. The first three values in row 15 show that the increase in the output of the higher education sector will be 0.0137 per unit increase in the final demand for manufacturing products, 0.0165 for light industry, and 0.0123 for building industry. The basic assumption of this multiplier explanation is that the intermediate demand for education of one unit of output in a production sector is fixed. Row 15 illustrates the effects on the outputs of the high education sector. The values in row 15 show that service has greater effects on the output of the high education sector than those of any other production sectors. The impacts of government investment in education be divided into direct influence, total influence and global influence. The direct influence shows the change in i induced by a unitary change in $\mathrm{j}$, with all others poles except those along the selected elementary path remaining constant. The total influence is calculated by multiplying the direct influence by a path multiplier that captures the multitude of interactions between $\mathrm{j}$ and $\mathrm{i}$ via the path. The global influence is the sum of total influences from $\mathrm{j}$ to $\mathrm{i}$ over all possible paths which is equal to the SAM multiplier Ma.

Table3. Selected results from the structural path analysis

\begin{tabular}{|c|c|c|c|c|c|c|c|}
\hline Path origin & Path destination & Global effect & Elementary path & Direct effect & $\begin{array}{l}\text { Path } \\
\text { multiplier }\end{array}$ & Total effect & $\%$ of global \\
\hline \multirow{3}{*}{$\begin{array}{l}\text { Higher education } \\
\text { (Hedu) }\end{array}$} & \multirow{3}{*}{$\begin{array}{l}\text { Service industry } \\
\text { (ser) }\end{array}$} & \multirow[t]{3}{*}{0.4503} & Hedu-ser & 0.18644 & 0.012 & 0.00224 & 0.49684 \\
\hline & & & Hedu-light-ser & 0.00629 & 0.015 & 0.00009 & 0.02096 \\
\hline & & & Hedu-trans-ser & 0.00467 & 0.014 & 0.00007 & 0.01450 \\
\hline \multirow{2}{*}{$\begin{array}{l}\text { Higher education } \\
\text { (Hedu) }\end{array}$} & \multirow{2}{*}{$\begin{array}{l}\text { Building industry } \\
\text { (build) }\end{array}$} & \multirow[t]{2}{*}{0.0130} & Hedu-build & 0.00482 & 0.212 & 0.00102 & 7.14573 \\
\hline & & & Hedu-ur-build & 0.00005 & 0.251 & 0.00001 & 0.08523 \\
\hline $\begin{array}{l}\text { Higher education } \\
\text { (Hedu) }\end{array}$ & $\begin{array}{l}\text { General business } \\
(\mathrm{gb})\end{array}$ & 0.1911 & Hedu-netc-gb & 0.00140 & 0.026 & 0.00004 & 0.01911 \\
\hline $\begin{array}{l}\text { Higher education } \\
\text { (Hedu) }\end{array}$ & $\begin{array}{l}\text { Educational } \\
\text { institutions } \\
\text { (edui) }\end{array}$ & 0.0391 & Hedu-netc-edui & 0.00029 & 0.026 & 0.00001 & 0.01913 \\
\hline \multirow{2}{*}{$\begin{array}{l}\text { Higher education } \\
\text { (Hedu) }\end{array}$} & \multirow{2}{*}{$\begin{array}{l}\text { Urban residents } \\
\text { (ur) }\end{array}$} & \multirow[t]{2}{*}{0.1897} & Hedu-hlabor-ur & 0.02520 & 0.045 & 0.00113 & 0.59779 \\
\hline & & & Hedu-netc-ur & 0.01005 & 0.045 & 0.00045 & 0.23848 \\
\hline $\begin{array}{l}\text { Urban residents } \\
\text { (ur) }\end{array}$ & $\begin{array}{l}\text { Higher education } \\
\text { (Hedu) }\end{array}$ & 0.0446 & ur-Hedu & 0.03072 & 0.190 & 0.00584 & 13.08700 \\
\hline
\end{tabular}

Table3 illustrates several selected results of the SPA. The results show that we can adopt the SPA to explore the interactions between a production and education activity in an ESAM. The global influence 
of higher education on service is traced out through the links between the two sectors. The first three rows of table 3 reveal that about $48.5 \%$ of the global influence $(0.4503)$ of higher education on service is induced via the indirect channels between the two sectors. The path via light industry contributes $17.9 \%$ (of the global influence), and the path via transportation industry $13.5 \%$. The second group of results shows that the global influence of higher education on building accrues differently. The global influences of higher education on institutions and urban residents are decomposed in the third and fourth blocks of Table3.In turn, the global influences of urban residents on higher education are decomposed in the fifth blocks of Table3.

\section{Conclusions}

SAM is one of the most important methods studying effects of government investment in education and economic. This paper took Inner Mongolia as an example to explain how to extend the traditional SAM, and adopt multiplier and structural path analyses to analyze the links between education and economic in the numerical ESAM. The analysis results reveal that increasing educational investment has played a significant role in the development of education and economic, while it can promote the development of other industries. Among them, service industry has the greatest global effects by 0.4503. And government educational investment has much great effects on general business than educational institutions by $66 \%$. Also government investments on higher education can affect urban residents indirectly through high-level labor or net capital, and the former plays an obvious role on urban residents than the latter. In short, the ESAM is an effective tool to evaluate the economic impact in education-related policy analysis.

\section{Acknowledgments}

This work is financially supported by the National Natural Science Foundation of China (71163031, 71363037).

\section{References}

[1] Nooraddin Sharify and Peter Batey, The Annals of Regional Science, vol.40, no.3, pp.639-660, 2006.

[2] Kermal Dervis, Jaime de Malo and Sherman Robinson, ournal of Development Economics, vol.14, no.1, pp.259-264, 1984.

[3] Qiwen Wang, Shantong Li, Social Accounting Matrix: Principles, Methods and Applications, Beijing: Tsinghua University Press, China,2008. (in Chinese)

[4] Ji H, The impact of public educational expenditures on educational equity and regional human capital growth: A financial computable general equilibrium model for Korea, Cornell University, New York, America,1999.

[5] Jinqing Zhu, Jianjun Wang, The Impact of Public Education Expenditure on Human Capital-Growth in Xinjiang, Xinjiang University of Finance and Economics, China,2011. (in Chinese)

[6] Wassily Leontief,Review of Economics and Statistics, vol.52, no.3, pp.262-271, 1970.

[7] State Statistical Bureau (SSB) of China (2010), 2007 Input-Output Table of China. Beijing: China Statistical Publishing House. 